\title{
CLINICAL AND LABORATORY FINDINGS OF 53 CASES WITH ACUTE BRUCELLOSIS
}

\author{
AKUT BRUSELLOZLU 53 OLGUDA KLINIIK VE LABORATUVAR \\ BULGULARI
}

\author{
Guilsen OKAN \\ Mehmet CANDAN \\ Cemille ÇAKMAK \\ Ayşegüil BARIŞ
}

\section{SUMMARY}

In this study, clinical and laboratory findings of fifty- three cases with acute brucellosis who admitted to the hospital with certain complaints were evaluated.

The most common complaints were as follows: Fever (93\%), artralgia (93\%), sweating (81\%), myalgia (79\%), headache (79\%) weakness (75\%). Common physical findings were $(71 \%)$, hepatomegaly (75\%), splenomegaly (26\%), lymphadenopathy (30\%), anemia (50\%). Elevated erytrocyte sedimentation rate was $35 \%$, and increased level of transaminases was $22 \%$. $37 \%$ of the patients gave history of consumption of fresh white cheese.

(Key words: Brusellosis, Symptomatology, Physical Exemination, Neurobrucellosis.)

\section{ÖZET}

Bu çalışmada değişik yakınmalarla hastanemize başvurup akut bruselloz tanısı alan 53 hasta, klinik ve laboratuvar bulgularıla değerlendirildi.

En sık yakınmalar şunlardır: Ateş (\%93), artralji (\%93), terleme (\%81), myalji (\%79), halsizlik (\%75), başağrısı (\%75). En sık fizik muayene bulguları ateş (\%71), hepatomegali (\%75), splenomegali (\%26), lenfadenopati (\%30) bulundu. Anormal Laboratuvar bulgular1 ise anemi (\%50), artmış sedimentasyon hızı (\%35), artmış transaminaz düzeyi (\%22) idi. Hastaların verdiği anammez de taze peynir yeme alışkanlığının (\%35) sıklikta olduğu görüldü.

(Anahtar Sözcüler: Bruselloz, Semptomlar, Fizik Muayene, Nörobruselloz).

Department of Infectious Disease and Clinical Microbiology,

(G. Okan M. D., Chief of Dept., C. Çakmak M.D.,

M. Candan MD. A. Barış M.D.)

SSK Tepecik Teaching Hospital

Correspondent: M. Candan, M.D.

SSK Tepecik Eğitim Hastanesi

Intaniye Kli. 35120 izmir - TURKEV 
Brucellosis is an infectious, zoonotic disease with systemic manifestations seen in man and animals (9). Human brucellosis is a world-wide health problem (7). It is common in areas where domestic animals harboring brucella are raised, adequate control measures are lacking and the population has the custom of ingesting unpasteurised milk or its products (17). The signs and symptoms associated with brucellosis are exceedingly non specific $(1,5)$. Most physicians prefer to consider brucellosis in a setting of persistant chills and fever but none of the clinical findings can be considered as characteristic for the disease (9).

The clinical spectrum varies from acute systemic, subacute (localized) to chronic illness (9)

This study was carried out to investigate the history, routes of spread, physical and labotory findings brucellosis.

\section{MATERIAL AND METHOD}

Fifty-three adult patients, (14-71) having complaints compatible with brucellosis and diagnosed as brucellosis between February 1990- January 1994 were admitted to the department of Infectious Diseases and Clinical Microbology, SSK Tepecik Teaching Hospital.

Every patient was given an application form where the history, physical examination was done and standart tube agglutination (STA), Coombs test, whole blood cells counting (WBC), eryrocyte sedimentation rate (ESR), sacroiliac $x$-rays were evalauted. Bone marrow specimens were taken from 6 patients and in 4 of them were positive. Venous blood samples were taken from 30 patients and 5 of which are positive for Brucellosis.

Venous blood or bone marrow aspiration samples taken from the sternum were inoculated to the media containing Brucella Broth (Difco) and the culture bottles were incubated at $37 C^{\prime}$ for 21 days.

\section{RESULTS}

History, spread of route, physical and laboratory findings of the patients are shown in tables 1-4.

Three of the cases were neurobrucellosis. In one case, vision of the both eyes were lost, with positive serological tests, culture and clinical improvement with appropriate therapy, it was considered as brucella optic neuritis. Two other cases were brucella meningitis. They showed positive signs of meningeal irritation. The cerebrospinal fluid showed a lymphocytic cellular reaction and moderate elevation of the protein content. Serology for brucellosis in the cerebrospinal fluid was positive (Rose Bengal, STA).

TABLE 1

\begin{tabular}{lll}
\hline Complaints & \multicolumn{2}{l}{ All Patients: 53} \\
\cline { 2 - 3 } Fever & 49 & $\%$ \\
Artralgia & 49 & 93 \\
Sweating & 43 & 81 \\
Myalgia & 42 & 79 \\
Headache & 42 & 79 \\
Anorexia & 41 & 77 \\
Weakness & 40 & 75 \\
Loss of weight & 36 & 67 \\
Abdominal pain & 20 & 37 \\
Chill & 7 & 13 \\
Coughing & 4 & 7.5 \\
Loss of visual acuity & 1 & 1.8 \\
\hline
\end{tabular}

TABLE 2

\begin{tabular}{lll}
\hline Spread route & Positive & $\%$ \\
\hline Ingesting fresh white cheese & 30 & 56 \\
Ingesting fresh butter & 20 & 37 \\
Ingesting raw milk & 3 & 5.6 \\
Profession husbandry & 15 & 28 \\
Slaughter house worker & 2 & 3.7 \\
Milk industry workers & 1 & 1.8 \\
Abortion in animals in the history & 7 & 1.8 \\
Butcher & 2 & 13 \\
Positive family history & 6 & 11 \\
\hline
\end{tabular}

TABLE 3

\begin{tabular}{lll}
\hline Physical findings & All patients: $53 \%$ \\
\hline Fever & 38 & 71 \\
Hepatomegaly & 40 & 75 \\
Splenomegaly & 14 & 26 \\
Lymhadenopathy & 16 & 30 \\
Closing of Traube & 10 & 18 \\
Mononeuritis & 1 & 1.8 \\
Meningeal Irritation & -3 & 5.6 \\
\hline
\end{tabular}


TABLE 4

\begin{tabular}{lll}
\hline Laboratory Findings & Patients \\
\hline & Number & $\%$ \\
\cline { 2 - 3 } Standart tube agglutination & 53 & 100 \\
Bone marrow culture (done 6$)$ & 4 & 66 \\
Blood culture (done 30) & 5 & 16.6 \\
CRP-positive & 39 & 73 \\
ESR (>50mm/h) & 19 & 35 \\
Anemia (Hb<10gm/d1) & 27 & 50 \\
Sacroiliitis & 19 & 35 \\
Increased transaminases level & 12 & 22 \\
Leucopenia & 6 & 11 \\
Pancytopenia & 2 & 3.7 \\
Lymphocytosis & 40 & 75 \\
Spondilodiscitis & 2 & 3.7 \\
\hline
\end{tabular}

\section{DISCUSSION}

Brucellosis in man and animals remains a public health and economic problem in the mediterranean countries. .Fresh cheese and raw milk from infected animals with brucellosis are the most common vectors of human infection $(4,9)$. In our study. $30(56 \%)$ patients had the history of ingestion of fresh cheese and $3(5.6 \%)$ had the history of ingestion of raw milk. Inapparent form of the disease as frequent. Acute brucellosis may of ten be confused with another infection and empirical antibiotic treatment blurs the signs of the disease $(14,17)$. In patients who take antibiotics before the blood cultures, isolation of organisms and serological diagnosis are more difficult and spesific therapy is often late $(4,6,7,9)$. In this study $38(71$ $\%)$ patients had nonspesific antibiotherapy before the diagnosis. In another study this was $72 \%$ (10). The musculoskeletal manifestations occur in $20-80 \%$ of patients. The major manifestations are polyartralgias, septic or sterile arthritis, sacroiliitis, spondylitis, tenosynovitis, bursitis and osteomyelitis. Sacroileitis is the most common form of articular involvement occurring in about $46 \%$ of patients who develop arthritis (3). Arthalgias are found in 55-79 \%, and myalgias in $24-52 \%$ of the patients. $(5,11)$ In this study, the patients had the symptoms of artralgia $(93 \%)$, myalgia $(79 \%)$, sacroiliitis $(22.6 \%$ ) , spondylodiscitis $(3.7 \%)$.
According to the literature $(7,9,10,14)$ splenomegaly and hepatomegaly 20-40\% and $25-50 \%$, respectively are found in with brucellosis. On the other hand the hepatosplenomegaly rate in brucellosis in Turkey is much higher $(20-60 \%)(2,4,10,14,17)$. In this study splenomegaly was found in $26 \%$, hepatomegaly in $75 \%$ and lymphadenopathy 30 $\%$ of the cases.

Central nervous system (CNS) involment in systemic brucellosis is not very common $(13,15,18$,$) . The incidence of neurobrucello-$ sis is given as 3-5\% by Shakir et al (15). The presentation of neurobrucellosis is diverse. Nervous system both central and periferal can be involved $(11,15,16,18)$.

In this study three cases were neurobrucellosis. The first had optic neuritis, second had spondylodiscitis and meningitis and the last had arachnoiditis and meningitis.

Hepatitis occurs in 30-90\% of patients with brucellosis and is characterized by increased levels of transaminases $(9,14)$. In this study, abdominal pain was found in 37 $\%$, increased transaminases levels in $22.6 \%$ and loss of weight in $67 \%$. Hematological abnormalities such as anemia, leukopenia, and thrombocytopenia are common accompaniments of brucellosis. The present study revealed anemia in $50 \%$ and leukopenia in $11.3 \%$ and pancytopenia $3.7 \%$, of the patients.

High serum C-reactive protein (CRP) assay is a helpful adjunct in the diagnosis, and in monitoring the treatment of patients with brucellosis (5). In this study C-reactive protein was found $39(\% 73)$ positive.

Ingestion of contaminated diary products is an important route of infection. Whether human begins can become infected via person to person spread is uncertain. However, Ruben et al (12) report that brucellosis may be a sexually transmitted disease. In another study it was reported that brucellosis affected family members; 33 patients were diagnosed brucellosis, coming from 12 different families (8). In this study, $6(11 \%)$ patients gave positive family history. 
Culture of the organism has proved difficulty for some investigators $(4,6,14)$. In a study it was reported that blood cultures were found to be positive in $36 \%$ (4). In 1972 , only $20 \%$ of the cases reported to the Center for Disease Control were culture proven. With the introduction of the double phase Ruiz-Castaneda's medium the rate of recovery of the Brucella organism has improved. Gotuzzo et al (6) reported that they had been routinely performing bone marrow cultures on this special medium since 1976 , and the rate of recovery had increased from $35 \%$ to $92 \%$. Some investigators report good recovery from bone marrow material $(6,7,13-15)$. In our study instead of biphasic blood culture bottles (Castaneda), we used blood culture medium contained Brucella broth (Difco). In this study blood cultures and bone marrow cultures were found to be positive $16.6 \%$ and $66 \%$, respectively.

In conslusion, to prevent human brucellosis milk and diary products should be pasteurized, especially in areas where brucellosis is common in cattle, goat or sheep. The importance of this health problem should be emphasized.

* Acknowledgement:

We thank Dr. Deniz Egeli for her support to English grammer.

\section{REFERENCES}

1. Açikel Ü, Çatalyürek $H$, Güneri $S$, et al : Bir brucella endokardit olgusuna çift kapak replasmant. 9 Eylül Ünio Tip Fak Derg 1993 ; 7 (3) : 56-9.

2. Akova M, Uzun O, Akalin HE, etal: Qinolones in treatment of human brucellosis comparative with doxycycline-rifampine. Antimicrobial Agent Chemother 1993; $37: 183$
3. Ariza I Pujol M, Valverde I, Nolla JM, Rufi G: Brucellar sacroiliitis: Findings in 63 Episodes and Current Relevance. Clin Infect Dis 1993 ; 16: 761-5

4. Coşkun NA, Ural S, Müftüoğlu I, et al : An evalution of brucellosis hospitalized in the 1985-1991 period. Infeksiyon Derg $1993 ; 7$ (3-4) : 283-7.

5. Demirkan F, Akalın HE, Şimşek $H$ et al : Spontaneous peritonitis due to Brucella melitensis in patient with cirrhosis. Eur I Clin Microbiol Infect Dis $1993 ; 12: 66-7$.

6. Gotuzzo E, Carillo C, Guerra J, Liosa C : An evaluation of diagnostic methods for brucellosis-the value of bone marrow culture. IInfec Dis $1986 ; 153: 12$.

7. Hall WH, Khan My: Brucellosis in: Infectious Disease 4th Edition (Ed: Hoeprich PD Jordan MC). Philadelphia. JB Lippincott Comp. 1989 ; 1282-8.

8. Inci $R$, Inci $S$, Kalycıŏ̆lu $N$ : Aile içi bruselloz. Infeksiyon Derg $1993 ; 7$ (1-2): 67-8.

9. Kaye D: Brucellosis (ed:) Wilson JD, Braunwald E, Isselbacher KS, Petersdorf RG, Martin JB: Harrison's Principles of Internal Medicine 12th Edition, New York MC Graw Hill Inc 1991.

10. Kılı̧ SS, Felek S, Akbulut A, Kocabay K: A prospective review of 82 cases of Acute Brucellosis Infeksiyon Derg 6 (4) $275-277,1992$

11. Koçanogulları O, Yüce A: Spinal ekstradural brucella absesi Izmir Göğis Hast Derg 1987 ; 2(4) : 62-4.

12. Ruben Band JD, Wong $P$ et al: Person to person transmission of Brucella melitensis. Lancet, 1991 ; 337 (1) : 14-5.

13. Saleh MAD, Basim AY, Hassan SS, Jagent GP : Neurobrucellosis : Clinical characteristics, diagnosis and outcome. Neurology $1989 ; 39$ (4) : 498.

14. Serter D, Yüce A, Günhan C, etal: Tifo Bruselloz olgularında karacĭ̆er fonksiyon testlerindeki değişiklikler. Ege Üniv Tup Fak Derg. 1982 ; 21 (1) : 41-6.

15.Shakir RA, Aldin AS, Araj GF, Lulu AR Mousa AR Saadah MA: Clintcal categories of neurobrucellosis. Brain $1987 ; 110: 213-23$.

16. Tekkök IH, Berber M, Özcan DE, et al: Brucellosis of the spine. Neurosurgery, $1993 ; 33: 838$.

17. Yüce $A$ : Klinik ve laboratuvar bulgularna göre bruselloz. İzmir Göğüs Hast. Derg. !968; 1(1) : 65-8.

18. Yüce A, Idiman E, Canda T, et al : Nörobruselloz. Nörol Bil Derg. $1989 ; 1: 37-40$. 